ПРАВА ИЗ ЗДРАВСТВЕНОГ ОСИГУРАЫА У РЕПУБЛИЦИ СРБИЈИ (1922-2015)

Рајко Косановић ${ }^{1}$ Христо Анђелски ${ }^{2}$

\title{
RIGHTS FROM HEALTH INSURANCE IN THE REPUBLIC OF SERBIA (1922-2015)
}

Rajko Kosanović, Hristo Anđelski

\section{Сажетак}

У правном систему савремених држава значајно место припада здравственом законодавству, односно законодавству које регулише област здравствене заштите и здравственог осигурања.

Циљ рада је израда приказа садржаја права из области здравственог осигурања у Републици Србији у периоду од 1922. године (од доношења Закона о осигурағу радника) до данас.

Анализирани су: Закон о осигурану радника из 1922. године, Закон о спровођењу сочијалног осигураға на подручју Демократске Федеративне Југославије из 1945. године, Закон о соиијалном осигурању радника, намештеника и службеника из 1946. године, Закон о соиијалном осигурағу радника и службеника и нихових породица из 1950. године, Закон о здравственом осигурану радника и службеника из 1954. године, Уредба о фондовима за узајамно помагање из 1956. године, Закон о установљену здравственог осигурања пољопривредних произвођача из 1959. године, Закон о здравственом осигурану из 1962. године, Onшти закон о здравственом осигурану $и$ обавезним видовима здравствене заштите становништва из 1969. године, Закон о здравственом осигурану и обавезним видовима здравствене заштите становништва из 1970. године, Закон о здравственој заштити из 1979. године, Закон о здравственој заштити из 1990. године, Закон о здравственом осигурању из 1992. године, Закон о здравственом осигурању из 2005. године.

\section{Summary}

In the jurisdiction of modern States a sigf nificant role belongs to health legislation or the legislation that regulates the field of health care and health insurance.

The aim of this work is to making the display content of patient rights in the field of health insurance in the Republic of Serbia in the period from 1922 (the Act on the insurance of workers) till today.

We analyzed: the law on insurance of employees from 1922, law on the implementation of social insurance in the area of Democratic Federal Yugoslavia from 1945, the law on social insurance of workers, public employees and officials from 1946, the law on social insurance of workers and employees and their families from 1950, the law on health insurance of workers and employees from 1954, the regulation on the funds for mutual aid from 1956, the law on establishing the health insurance of farmers from 1959, Health Insurance Act from 1962, General Law on Health Insurance and obligatory forms of health care for the population from 1969, Law on Health Insurance and obligatory forms of health care for the population from 1970, Law on health care from 1979, the law on health care from 1990, the law on health insurance from 1992, the law on health insurance from 2005.

Reform of the health care system is a continuous and in advance well-designed process, supported by health legislation.

\footnotetext{
${ }^{1}$ Др сц. Рајко Косановић, Београд

${ }^{2}$ Проф. др Христо Анђелски, Висока медицинска школа струковних студија „Милутин Миланковић“, Црнотравска 27, Београд.
} 
Реформа система здравствене заштите је континуиран и унапред добро осмишьен прочес, подржан здравственим законодавством.

Кључне речи: здравствено законодавство, здравствено осигурање, историјски развој, Србија.
Key words: health legislation, health insurance, historical development, Serbia.

\section{УВОД}

$\mathrm{Y}$ правном систему савремених држава значајно место припада здравственом законодавству, односно законодавству које регулише област здравствене заштите и здравственог осигурања.

Развој здравственог законодавства у Републици Србији можемо пратити од средине деветнаестог века до данас. Међу законима којима су успостављени темељи система здравствене заштите, једно од централних места припада Закону о установљењу народног санитетског фонда, усвојеном у Краљевини Србије пре скоро 136 година, односно 28. децембра 1879. године, а који је ступио на снагу 1 . јануара 1881 . године.

Од доношења Закона о установљену народног санитетског фонда, па све до данас здравствено осигурање у Србији каракө терише динамичан развој, како у погледу организације и система финансирања, тако и у погледу садржаја и обима права. ${ }^{(1)}$

Здравствено осигурање је грана соиијалног осигурања, којим се осигураним лицима (осигураницима и члановима породице осигураника) обезбеђује право на здравствену заштиту и остала права из области здравственог осигурања (наканде осигураницимма).

Обавезно здравствено осигурағе заснива се на већем броју начела, односно принципа, од којих су основни: обавезности, узајамности и солидарности, јавности, заштите права осигураних лица и заштите јавног интереса, сталног унапређења квалитета, економичности и ефикасности и други принципи.

У овом раду дајемо приказ садржаја права из области здравственог осигурања у Републици Србији у периоду од 1922. године (од доношења Закона о осигурању радника) до данас.

\section{1. ЗАКОН О ОСИГУРАЫУ РАДНИКА ИЗ 1922. ГОДИНЕ}

Законом о осигурағу радника, који је потписан 14. маја 1922. године, а објављен 30. маја исте године, уведене су четири врсте обавезног осигурања и то за случајеве: а) болести, б) изнемоглости, старости и смрти, ц) несреће на послу, и д) незапослености. ${ }^{(2)}$

Осигурање за случај болести (здравствено) на територији целе државе извршено је 1922. године, као и осигурање за случај несреће на послу (инвалидско); осигурање за случај изнемоглости, старости и смрти (пензијско), иако је било прописано да ће се спроводити од 1. јула 1925. године, његово спровођење почело је тек 1. септембра 1937. године, али и тада у ограниченом обиму, а када је реч о осигурању за случај незапослености, оно је требало да буде уређено посебним прописима, међутим то није учињено нити је уведено, осим што је постојало само за рударе и топионичаре код главних братинских благајни.

Осигурање за случај болести обухватало је право осигураника на: 
a) бесплатну лекарску помоћ док траје болест узастопце за 26 недеља, која се могла продужити најдуже до 52 недеље;

б) лекове, купања, лековите воде, потребне завоје и помоћне справе за лечење (наочаре, штаке, потпасе, вештачке ноге), такође бесплатно за 26 недеља;

в) хранарину, ако је болесник неспособан за рад, а болест траје дуже од три дана, припадала је од дана настанка обољења, у висини 2/3 обезбеђене наднице дневно.

Осигурање за случај болести имале су и породиље и чланови породице осигураника.

У случају порођаја, осигуране жене имале су право на:

a) потребну примаљску (бабичку) помоћ и лечење, назначено у тач. 1;

б) потпору за породиље за време од 2 месеца пре и 2 месеца иза порођаја са 3/4 (три четвртине) обезбеђене наднице дневно;

в) потпору за опрему детета и то у четрнаестоструком износу обезбеђене наднице, али само у случају да је рођено живо дете;

г) потпору за дојење оним осигураним женама, које дете своје доје, за двадесет недеља по престанку потпоре за породиље с $1 / 2$ (половином) обезбеђене наднице, али највише до износа од 3 динара дневно.

Оне осигуране жене које према лекарској потврди нису биле у могућности да доје добијале су уместо припадајуће потпоре за дојење (тач. г) дечију храну, чија вредност није смела прелазити вредност припадајуће потпоре за дојење.

Чланови породице, у случају да нису били запослени, имали су права:

a) у случају болести: на бесплатно лечење, лекове, потребне помоћне справе за лечење кроз 26 недеља, али само док има и осигурани члан право на потпору;

б) у случају порођаја: на потребну примаљску помоћ и лечење и на потпору за породиље за време од четири недеље пре и четири иза порођаја у износу од 1,50 динара дневно, као и на потпору за опрему детета.

Под члановима породице подразумевали су се: венчани или невенчани брачни друг, брачна, ванбрачна или усвојена деца, родитељи, дед, баба, унуци, браћа и сестре осигураника.

У случају смрти осигураног члана законом било је утврђено право на погребнину и то у тридесетоструком износу обезбеђене наднице.

Претходно наведене потпоре пружали су осигураним члановима месни органи средишног уреда за осигурање радника у износу и на начин прописан статутом средишног уреда.

Допринос за случај болести, изнемоглости, старости и смрти храниоца плаћали су радници и послодавци, сваки са једном половином, а допринос за случај несреће на послу само послодавци.

Спровођење осигурања било је поверено Средишњем уреду за осигурање радника, са седиштем у Загребу и окружним уредима за осигурање радника. Поред ових органа постојали су: пензиони заводи за осигурање намештеника, братинске благајне за осигурање рудара и топионичара, трговачко болесничко осигурање и остала друштва.

\section{2. ЗАКОН О СПРОВОБЕНУ СОЦИЈАЛНОГ ОСИГУРАНА НА ПОДРУЧЈУ ДЕМОКРАТСКЕ ФЕДЕРАТИВНЕ ЈУГОСЛАВИЈЕ ИЗ 1945. ГОДИНЕ}

Након ослобођења Југославије, Председништво Антифашистичког већа народног ослобођења Југославије донело је 2. маја 1945. године Закон о спровођену соиијалног осигурања на подручју Демократске Федеративне Југославије. ${ }^{(3)}$

Једини носилац за спровођење осигуpaњa, на подручју целе државе, за случајеве: а) болести, б) изнемоглости, старости, смрти (пензионог осигурања), в) несреће и 
г) неупослености, био је Средишњи завод за соиијално осигурање са седиштем у Загребу, који је спроводио осигурање преко земаљских завода за сочијално осигурање, осниваних у седиштима федералних јединица.

Средишњи завод за соиијално осигурање спроводио је осигурање за случај изнемоглости, старости и смрти (пензионо осигурање), несреће и неупослености.

Земаљски заводи за соиијално осигурање, преко својих филијала, спроводили су осигурање за случај болести, а све остале врсте осигурања спроводили су као органи Средишњег завода.

\section{3. ЗАКОН О СОЦИЈАЛНОМ ОСИГУРАНУ РАДНИКА, НАМЕШТЕНИКА И СЛУЖБЕНИКА ИЗ 1946. ГОДИНЕ}

Закон о сочијалном осигурању радни$\kappa a$, намештеника и службеника Народна скупштина ФНРЈ донела је 26. јула 1946. године, а исти се примењивао од 1. јануаpa 1947. године. ${ }^{(4)}$ Овај закон имао је велики значај за развој социјалног осигурања, њиме су регулисане све гране социјалног осигурања, обухваћене су све категорије запослених лица, и знатно проширен обим права.

Радници, намештеници и службеници, по овом закону имали су право на државно соиијално осигурање, за случај болести, трудноће и порођаја, несреће на послу, изнемоглости, старости и смрти.

Социјално осигурање спроводила је држава преко Државног завода за соиијално осигурање и његових органа организованих на територијалној и професионалној основи, по начелу да се социјално осигурање што више приближи самим осигураницима. Ради остварења овог начела, предложено је да се служба социјалног осигурања, где год је то могуће, организује при самим предузећима.
Спорове између осигураника и Државног завода за социјално осигурање решавали су судови социјалног осигурања, организовани при окружним судовима.

У случају болести осигураник имао је право на:

а) бесплатну лекарску помоћ, бесплатне лекове, лековита купања, лековите воде, потребне завоје и помоћне справе за лечење, као и на бесплатну поправку зуба, и то за све време док ради, као и за време, док услед неспособности за рад прима новчану накнаду;

б) новчану накнаду за изгубљену зараду (болесничка хранарина) у висини од $50 \%$ до $100 \%$ од основа за новчана давања, ако је услед болести неспособан за рад и ако та неспособност траје дуже од 3 дана;

в) бесплатно болничко, санаторијско, бањско или климатско лечење, уместо давања из тач. а) и б) ако је услед болести неспособан за рад и ако му је такво лечење према лекарском налазу потребно, и то почевши од наступања неспособности за рад па за све време трајања права на хранарину; затим на накнаду доказаног стварног трошка путовања односно отпреме болесника од места његовог редовног боравка или седишта посла до места лечења и натраг;

г) на новчану потпору за издржавање породице у висини од $50 \%$ до $100 \%$ од хранарине или на новчану потпору за дневне ситне трошкове до висине једне петине хранарине ако не издржава породицу, и то за све време док се налази на болничком, санаторијском, бањском или климатском лечењу.

Члановима породице осигураника пружана су у случају њихове болести следећа давања:

a) бесплатна лекарска помоћ, бесплатни лекови, потребни завоји и потребне справе за лечење за време док болест траје, али највише за време од године дана за свако поједино обољење;

б) бесплатно болничко лечење у трајању од најдуже 6 месеци за поједино обољење. 
У случају смрти осигураника припадала је погребнина брачном другу а, ако овог није било, другим члановима породице или трећим лицима која су се побринула за погреб осигураника, а у случају смрти брачног друга, родитеља или деце осигураника припадала је погребнина осигуранику.

Право на давања у случају трудноће и порођаја имала је осигураница која је у последњој години пред порођајем била осигурана најмање 6 месеци или у последње 2 године најмање 12 месеци. Осигураниия имала је права на:

a) бесплатну лекарску или бабичку (примаљску) помоћ или на 14-дневну болничку или родилишну негу;

б) новчану накнаду за изгубљену зараду (породиљска хранарина) за време од 6 недеља пре порођаја и 6 недеља после поpoђaja;

в) новчану помоћ за опрему детета;

г) новчану помоћ за храну детета за време од три месеца по престанку породиљске хранарине.

Породиљска хранарина износила је најмање $75 \%$ а највише $100 \%$ од основа за новчана давања. Висина породиљске хранарине зависна је од броја дана стварно проведених на раду у последњих 5 година пре почетка права на ту помоћ.

Осигураник, када му се роди дете, имао је право, ако је у последњој години пре рођења детета био осигуран најмање 6 месеци или у последње две године најмање 12 месеци, на следећа давања:

a) на бесплатну лекарску или бабичку (примаљску помоћ) или 14-дневну болничку или родилишну негу за жену;

б) на новчану помоћ за опрему детета;

в) на новчану помоћ за храну детета за време од два месеца после порођаја.

Давања за случај порођаја пружала су се жени осигураника и у случају када је порођај уследио у року од 10 месеци после смрти осигураника, ако је осигураник за живота већ испунио услове за то право.
Државни завод за соичјално осигурање преузео је од 1. јануара 1947. године целокупну имовину и целокупно пословање Средишњег завода за социјално осигурање и његових органа без посебне ликвидације.

\section{4. ЗАКОН О СОЦИЈАЛНОМ ОСИГУРАНУ РАДНИКА И СЛУЖБЕНИКА И ЊИХОВИХ ПОРОДИЦА ИЗ 1950. ГОДИНЕ}

Законом о социјалном осигурању радника и службеника и њихових породица, донетим 21. јануара 1950. године, ${ }^{(5)}$ процес формирања државног соиијалног осигурања, започет доношењем Закона о социјалном осигурању радника, намештеника и службеника, 1946. године, доведен је до краја.

Држава социјалним осигурањем обезбеђује радницима и службеницима и њиховим породицама одређена права за случај болести, губитка способности за рад, старости, смрти и друга права утврђена овим законом.

Овим законом обезбеђивана су следећа права:

- право на здравствену заштиту;

- право на материјално обезбеђење за време привремене неспособности за рад услед болести;

- право на материјално обезбеђење за време одсуства због трудноће и порођаја;

- право на материјалну потпору за децу;

- право на материјално обезбеђење у случају смањења способности за рад (инвалиднина);

- право на други посао и право на оспособљавање за посао друге струке (преквалификација) у случају смањења способности за рад;

- право на инвалидску, старосну и породичну пензију;

- право на погребнину. 
Стицање и обим појединих права зависило је, по правилу, од трајања радног односа и висине плате.

Осигуранику се обезбеђивало право на здравствену заштиту у случају болести, односно у случају одсуства ради лечења или опоравка (боловање).

Здравствена заштита обухватала је: медицинску помоћ и лечење у здравственим установама или у стану болесниковом; лекове и друга лековита средства; справе за лечење и санитетски материјал; лечење у болницама и природним лечилиштима (бањама и климатским местима); опоравак у опоравилиштима после болести; породиљску негу; зубну негу и зубно-техничку помоћ; ортопедске и друге помоћне справе.

Осигураник који је услед болести, односно боловања привремено неспособан за рад имао је за време болести, односно боловања право на новчану накнаду уместо редовне плате.

Осигуранику који је непосредно пре почетка неспособности за рад био у радном односу непрекидно најмање шест месеци или с прекидима укупно осамнаест месеци за последње две године, припадала је за време лечења, односно боловања накнада једнака његовој редовној плати. Осигуранику који није имао одговарајући радни стаж припадала је за време лечења, односно боловања смањена накнада у висини од $50 \%$ редовне плате ако му радни стаж износио до три месеца, а у висини од 75 ако му радни стаж износио више од три месеца а мање од шест месеци.

Право на материјално обезбеђење припадало је без обзира на дужину радног стажа: осигуранику који је постао привремено неспособан за рад услед последица несреће на послу и осигуранику - ученику у привреди.

Осигураник - жена имала је право на материјално обезбеђење за све време одсуства због трудноће и порођаја. Трајање овог одсуства износило је три месеца.
Осигураницима су се за њихову децу обезбеђивала следећа права (материјална noтnора за децу): потпора за опрему новорођеног детета, потпора ради појачања исхране мајке и новорођеног детета, потпора породицама са више деце и стални новчани додатак на децу.

\section{5. ЗАКОН О ЗДРАВСТВЕНОМ ОСИГУРАНУ РАДНИКА И СЛУЖБЕНИКА ИЗ 1954. ГОДИНЕ}

Доношењем Закона о здравственом осигурағу радника и службеника, ${ }^{(6)} 1954$. године, Закона о пензијском осигурағу, (7) 1957. године и Закона о инвалидском осигурању, ${ }^{(8)}$ 1958. године, социјално осигурање организује се по гранама.

Према Закону о здравственом осигурању радника и службеника, права из здравственог осигурања су:

а) право на здравствену заштиту;

б) право на накнаду уместо плате за време привремене неспособности за рад услед болести и у другим случајевима одређеним овим законом;

в) право на накнаду уместо плате за време одсуства због трудноће и порођаја и право на помоћ за опрему новорођеног детета;

г) право на накнаду путних трошкова у вези са коришћењем здравствене заштите;

д) право на накнаду погребних трошкова и на посмртну помоћ.

Право на здравствену заштиту обухватало је:

- лекарске прегледе и лечење у здравственим установама и у стану болесника;

- давања лекова и других лековитих средстава и санитетског материјала потребног за лечење;

- лекарску и другу стручну негу и помоћ пре, за време и после порођаја у здравственим установама и у стану породиље;

- негу зуба (вађење, лечење и пломбирање зуба); 
- лечење са потпуном опскрбом у оним објектима природних лечилишта који су организовани као здравствене установе, кад је такво лечење неопходно.

Под посебним условима одређеним законом обезбеђивале су се и следеће врсте здравствене заштите:

- зуботехничка помоћ и зубна протетичка средства;

- протезе и друге ортопедске помоћне и санитарне справе;

- лечење у природним лечилиштима без опскрбе, кад је такво лечење корисно, али није неопходно.

Накнада уместо плате износила је:

- $80 \%$ од основа за накнаду за првих седам дана, а 90\% од основа за накнаду после седам дана - за осигуранике који су осигурани најмање шест месеци непрекидно или дванаест месеци са прекидима за последње две године непосредно пре почетка права на накнаду;

- $60 \%$ од основа за накнаду за првих седам дана, а 70\% од основа за накнаду после седам дана - за осигуранике који пре почетка права на накнаду нису осигурани шест месеци непрекидно или дванаест месеци са прекидима за последње две године.

Права у случају трудноће и порођаја била су накнада уместо плате и помоћ за опрему новорођеног детета.

Накнада уместо плате за време одсуства због трудноће и порођаја износила је:

- за осигуранике - жене које су осигуране најмање шест месеци непрекидно или дванаест месеци са прекидима за последње две године непосредно пре порођаја - 100\% од основа за накнаду;

- за осигуранике - жене које су осигуране мање од шест месеци непрекидно или мање од дванаест месеци са прекидима у последње две године непосредно пре поpoђаја $-80 \%$ од основа за накнаду.
Када је реч о помоћи за опрему новорођеног детета, скупштина среског (градског) завода за социјално осигурање, као и скупштина републичког (покрајинског, обласног) завода за социјално осигурање, могла је да одлучи да се помоћ за опрему новорођеног детета, уместо у новцу, даје било у опреми потребној за правилну негу детета, било делимично у новцу а делимично у опреми, с тим да укупна вредност ове помоћи требало је да одговара износу помоћи коју је одредило Савезно извршно веће.

Накнада путних трошкова обухватала је:

- накнаду за трошкове превоза и

- накнаду за трошкове опскрбе и смештаја за време путовања и боравка у другом месту.

У случају смрти осигураника, као и у случају смрти члана породице осигураникове, који има право на здравствено осигурање породици, односно осигуранику припадала је накнада на име трошкова сахране.

Здравствено осигурање, према Закону о здравственом осигурању радника и службеника, спроводили су заводи за социјално осигурање организовани за подручје среза (града) или за подручје више срезова, односно за подручје среза и града.

Финансијска средства за здравствено осигурање обезбеђивана су у фондовима здравственог осигурања, којима су управљали заводи за соиијално осигурање.

Фондови здравственог осигурања образовани си из доприноса који су плаћале привредне и друге организације, установе и послодавци за сва код њих запослена лица, као и други обвезници доприноса по посебним прописима. 
6. УРЕДБА О ФОНДОВИМА ЗА УЗАЈАМНО ПОМАГАНЕ ИЗ 1956. ГОДИНЕ

Доношењем Уредбе о фондовима за узајамно помагање, ${ }^{(9)} 1956$. године, у систем здравственог осигурања уводи се добровољно осигурање, независно од обавезног осигурања.

\section{7. ЗАКОН О УСТАНОВЉЕЫУ ЗДРАВСТВЕНОГ ОСИГУРАЫА ПОљОПРИВРЕДНИХ ПРОИЗВОЋАЧА ИЗ 1959. ГОДИНЕ}

Здравствено осигурање постаје потпуније доношењем Закона о установљењу здравственог осигурања пољопривредних произвођача, ${ }^{(10)} 1959$. године.

Здравствено осигурање пољопривредних произвођача могло је бити основно и проширено. Основним здравственим осигурањем обезбеђивао се законом одређени обим здравствене заштите, а проширеним здравствена заштита у ширем обиму, као и коришћење под повољнијим условима оне здравствене заштите која се обезбеђивала основним здравственим осигурањем.

Основним здравственим осигурањем обезбеђивало се:

- лечење у свим здравственим установама у случају обољења од колере, куге, жуте грознице, великих богиња, пегавца и других болести утврђених законом;

- лечење у одговарајућим здравственим установама у случају обољења од душевних болести, када је оболело лице опасно по живот других лица;

- вакцинисање, кад је оно обавезно по посебним прописима;

- дезинфекција, дезинсекција и дератизација у стану, кад су медицински индицирани због појаве заразне болести.

За спровођење здравственог осигурања пољопривредних произвођача образова- ни су фондови здравственог осигурања пољопривредних произвођача у оквиру среских завода за соиијално осигурање.

\section{8. ЗАКОН О ЗДРАВСТВЕНОМ ОСИГУРАНУ ИЗ 1962. ГОДИНЕ}

Закон о здравственом осигурағу ${ }^{(11)}$ објављен је у „Службеном листу ФНРЈ“, од 30. маја 1962. године, а ступио је на снагу осмог дана по објављивању. Допуне овог закона вршене су у децембру исте године.

Доношењем Закона о изменама и допунама Закона о здравственом осигурању, ${ }^{(12)}$ априла 1965. године, назив закона мења се и гласи Основни закон о здравственом осигуpaъy. Измене и допуне овог закона вршене су наредне 1966. (два пута) и 1967. године.

Здравственим осигурањем, у случајевима и под условима одређеним овим законом, обезбеђивана су следећа права:

1) осигураницима

а) здравствена заштита,

б) накнада личног дохотка односно плате (у даљем тексту: накнада личног дохотка),

в) накнада путних трошкова у вези са коришћењем здравствене заштите,

2) члановима породица осигураника

а) здравствена заштита,

б) накнада путних трошкова у вези са коришћењем здравствене заштите.

У оквиру здравственог осигурања осигураним лицима обезбеђивана су, под одређеним условима, и новчана примања за случај рођења детета и за случај смрти осигураног лица.

Здравствена заштита која се овим законом обезбеђивала, обухватала је:

1) лекарске прегледе и друге врсте медицинске помоћи у циљу праћења и проверавања здравственог стања и утврђивања здравствене способности за рад на одређеном радном месту или за војну службу, 
2) предузимање стручних медицинских мера за унапређивање здравственог стања односно спречавање обољења (вакцинације и друге имунизације, хемио-профилакса, санирање клицоноша, дезинфекција и друге заштитне мере у стану, кад су медицински индициране услед појаве заразне болести, и др.),

3) лекарске прегледе, лечење болесника, друге врсте медицинске помоћи и медицинску рехабилитацију (у здравственим и другим специјализованим установама, стану болесника, и сл.),

4) превенцију, негу и лечење болести зуба и уста,

5) лекарску и другу стручну негу и помоћ пре, за време и после порођаја, у здравственим установама и у стану породиље,

6) давање лекова, помоћног материјала који служи за употребу лека и санитетског материјала потребног за лечење,

7) зубнотехничку помоћ и зубнопротетичка средства,

8) протезе, ортопедска и друга помагала, помоћне и санитарне справе.

Накнада личног дохотка износила је:

1) $80 \%$ од основа за накнаду за првих седам дана, 90\% од основа од осмог до шездесетог дана и 100\% од основа од шездесет и првог дана изостанка са посла - осигуранику који је пре наступања случаја који даје право на накнаду личног дохотка испуњавао услов претходног осигурања,

2) $60 \%$ од основа за накнаду за првих седам дана, 70\% од основа од осмог до шездесетог дана и $100 \%$ од основа од шездесет и првог дана изостанка са посла - осигуранику који није испуњавао услов претходног осигурања.

Накнада личног дохотка у висини 100\% од основа за накнаду припада од првог дана изостанка са посла:

1) осигураницима чија је привремена неспособност за рад проузрокована несрећом на послу или професионалним обољењем,
2) ученицима у привреди и ученицима стручних школа са практичном обуком,

3) осигураницима одређеним за пратиоце болесника.

Осигураницима који су били осигурани по овом закону припада помоћ за опрему за свако новорођено дете, и то:

1) осигуранику - жени,

2) осигуранику - мушкарцу, за случај порођаја његовог брачног друга који је осигуран као члан његове породице,

3) осигуранику, за случај порођаја ма ког другог женског лица које је осигурано као члан његове породице, ако осигураник непосредно пре рођења детета испуњава услов претходног осигурања.

Помоћ за опрему новорођеног детета припадала је и у случају порођаја женског члана породице коме се обезбеђује здравствена заштита док се лице по ком има право на ту заштиту налази на одслужењу војног рока.

Помоћ за опрему новорођеног детета припадала је и:

1) за дете рођено у року од 10 месеци од дана смрти осигураника, односно после развода брака са осигураником коме припада ова помоћ,

2) за ванбрачно дете осигураника, ако је очинство утврђено на основу признања или судског установљења,

3) за усвојено дете до 6 месеци живота ако за то дете помоћ већ није исплаћена.

Средства за обезбеђене права из здравственог осигураға остваривана су доприносима од којих су образовани фондови здравственог осигурања код комуналних завода за социјално осигурање, сагласно одредбама Закона о организацији и финансирању социјалног осигурања.

При коришћењу одређених видова здравствене заштите, осигурана лица учествовала су у сношењу дела трошкова здравствене заштите. 


\section{9. ОПНТИ ЗАКОН О}

\section{ЗДРАВСТВЕНОМ ОСИГУРАЫУ И ОБАВЕЗНИМ ВИДОВИМА ЗДРАВСТВЕНЕ ЗАШТИТЕ СТАНОВНИШТВА ИЗ 1969. ГОДИНЕ}

Општи закон о здравственом осигурању и обавезним видовима здравствене заштите становништва, ${ }^{(13)}$ усвојила је Савезна скупштина, на седници Савезног већа, 24. априла 1969. године и на седници Социјално-здравственог већа, 25. априла 1969. године и исти је објављен 8. маја 1969. године.

Општи закон о здравственом осигурању и обавезним видовима здравствене заштите становништва је последњи закон из области здравствене заштите и здравственог осигурања који је донет на савезном нивоу.

Права из здравственог осигураға предвиђена Општим законом о здравственом осигурању и обавезним видовима здравствене заштите становништва, која осигураници за себе и чланове својих породица у заједницама здравственог осигурања обезбеђују су:

- здравствена заштита коју самостално утврђују у оквиру заједнице здравственог осигурања;

- здравствена заштита која се на основу закона обавезно обезбеђује и спроводи путем здравственог осигурања;

- новчане накнаде и помоћи које осигураним лицима припадају на основу овог закона односно које заједница здравственог осигурања установи;

- друга права из здравственог осигурања која самостално утврђују заједнице здравственог осигурања.

Обавезни видови здравствене заштите који су се обезбеђивали свима били су:

a) откривање, спречавање, сузбијање и лечење туберкулозе, венеричних и других заразних болести које подлежу обавезном пријављивању; б) нега и лечење оних душевних болесника који, због природе и стања болести, могу да угрозе свој живот и живот других људи или оштете материјална добра околине;

в) здравствена заштита жена у вези са трудноћом, порођајем, материнством и контрацепцијом;

г) потпуна здравствена заштита новорођенчади, одојчади и предшколске деце;

д) здравствена заштита школске деце, школске омладине и редовних студената до одређеног узраста, и то путем: систематских прегледа, заштите и лечења зуба; спречавања, сузбијања и лечења реуматичне грознице; протетичких и рехабилитационих мера код општећења и аномалија вида и слуха и код ортопедских аномалија и деформитета;

ђ) активности на раном откривању малигних обољења и шећерне болести и њихово лечење;

е) активност на здравственом васпитању становништва.

За случај несреће на послу и обољења од професионалних болести осигураницима - радницима обавезно су се обезбеђивала права на:

a) коришћење здравствене заштите и спровођење мера у циљу откривања и спречавања обољења од професионалних болести и несрећа на послу;

б) коришћење свих врста медицинске помоћи и ортопедских средстава у циљу лечења и рехабилитације од последица несреће на послу и обољења од професионалних болести ради успостављања радне способности;

в) накнаду личног дохотка за све време трајања привремене спречености за рад проузроковане несрећом на послу, односно обољењем од професионалне болести и путне трошкове у вези са коришћењем здравствене заштите и рехабилитације. 
Права из осигурања за случај несреће на послу и обољења од професионалних болести обезбеђивала су се осигураницима независно од дужине претходног трајања здравственог осигурања.

Основ за накнаду личног дохотка за време привремене спречености за рад чини просек личног дохотка који је радник остварио у претходној години пре године у којој је наступио случај по коме се стиче право на накнаду.

Висину накнаде личног дохотка која се исплаћивала на терет средстава заједнице здравственог осигурања, односно на терет средстава приватног послодавца, утврђивала је заједница здравственог осигурања, а висину накнаде коју је исплаћивала радна организација утврђивала је сама радна организација.

Накнада личног дохотка одређивана је најмање у висини од $60 \%$ од основа за накнаду, с тим да није могла бити нижа од износа минималног личног дохотка утврђеног важећим прописима.

Висина накнаде износила је $100 \%$ од основа за накнаду:

- за време привремене спречености, за рад проузроковане несрећом на послу или обољењем од професионалне болести, ако се ради о накнади коју утврђује заједница здравственог осигурања;

- за време одсуства због трудноће и поpoђaja.

Здравствено осигурање обезбеђивали су осигураници по начелима узајамности и солидарности, у оквиру самоуправних заједница здравственог осигурања. Највиши орган управљања заједнице здравственог осигурања била је скупштина.

Заједнице су се образовале као заједнице здравственог осигурања радника, заједнице здравственог осигурања земљорадника и заједнице здравственог осигурања лииа која врше самосталне професионалне делатности. Заједнице истих категорија, односно различитих категорија могле су се спојити или раздвојити, по поступку и на начин одређен законом.

Средства за остваривање здравствене заштите и других права из здравственог осигурања обезбеђивна су доприносом осигураника и законом утврђених других обвезника плаћања доприноса, учешћем друштвено-политичких заједница и другим приходима.

\section{0. ЗАКОН О ЗДРАВСТВЕНОМ ОСИГУРАНУ И ОБАВЕЗНИМ ВИДОВИМА ЗДРАВСТВЕНЕ ЗАШТИТЕ СТАНОВНИШТВА ИЗ 1970. ГОДИНЕ}

Републички Закон о здравственом осигурању и обавезним видовима здравствене заштите становништва ${ }^{(14)}$ Скупштина Coцијалистичке Републике Србије донела је 10. јула 1970. године, исти је објављен 18. јула 1970. године. Закон је ступио на снагу од наредног дана од дана објављивања у Службеном гласику Социјалистичке Републике Србије, а примењивао се од 1. јануара 1971. године.

Права из здравственог осигурања, предвиђена овим законом су:

а) здравствена заштита коју осигураници самостално утврђују у оквиру заједнице;

б) здравствена заштита која се на основу закона обавезно обезбеђује и спроводи путем здравственог осигурања;

в) новчане накнаде и помоћи које осигураним лицима припадају на основу закона, односно које заједница установи;

г) друга права из здравственог осигурања која самостално утврђују заједнице.

Обавезни видови здравствене заштите који се осигуравају и обезбеђују осигураним лицима и лицима која нису обухваћена обавезним здравственим осигурањем били cy:

a) Откривање, спречавање, сузбијање и лечење туберкулозе, венеричних и других заразних болести које обухвата: 
- систематске прегледе становништва у циљу откривања болести: пријављивање, имунизацију, хемио и дератизацију, епидемиолошки надзор над одређеним особама, активно епидемиолошко испитивање и потраживање посете;

- изолацију, превоз, преглед и лечење у свим здравственим организацијама или у стану болесника и давање лекова.

б) Нега, лечење и превоз душевних болесника који због природе и стања болести могу да угрозе свој живот и живот других људи или да оштете материјална добра околине, које обухвата:

- пријављивање, патронажне посете, преглед и лечење у свим здравственим организацијама или у стану и давање специфичних лекова (психофармака).

в) Здравствена заштита жена у вези са трудноћом, порођајем, материнством и контрацепцијом која обухвата:

- стручну контролу у току трудноће, амбулантно и болничко лечење и давање специфичних лекова код патолошких трудноћа;

- стручну помоћ код порођаја у здравственој организацији или стану;

- контролу здравственог стања жене после порођаја, амбулантно и болничко лечење и давање лекова код последица трудноће и порођаја до 6 месеци после порођаја;

- саветовање о примени и давање контрацептивних средстава;

- заштиту и лечење зуба у току трудноће и 6 месеци после порођаја (без протетике).

г) Потпуна здравствена заштита деце до навршене 15. године живота која обухвата:

- стручну контролу психичког и физичког развоја, патронажне посете, здравствени надзор над установама за децу;

- преглед, лечење и рехабилитацију у свим здравственим организацијама или у стану и давање лекова, смештај и опскр- бу у свим здравственим организацијама мајке дојиље болесног детета до једне године живота, заштиту и лечење зуба.

д) Потпуна здравствена заштита школске омладине и студената виших и високих школа, факултета и уметничких академија до краја прописаног редовног школовања, али најдоцније до навршене 26. године живота која обухвата:

- систематске прегледе, здравствени надзор над школама, школским објектима и објектима за колективно становање;

- преглед, лечење и рехабилитацију у свим здравственим организацијама или у стану, давање лекова и свих врста ортопедских и протетичких помагала;

- заштиту и лечење зуба.

ђ) Здравствена заштита омладине до навршене 26. године живота која обухвата: спречавање, сузбијање и лечење реуматске грознице (и компликација) у свим здравственим организацијама или у стану и употребу одговарајућих лекова.

е) Мере за рано откривање и лечење малигних обољења које обухватају:

- пријављивање, систематске прегледе и патронажне посете;

- преглед и лечење у свим здравственим организацијама или у стану и давање лекова.

ж) Мере на превенцији, раном откривању и лечењу шећерне болести које обухватају:

- пријављивање, систематске прегледе, обезбеђење прибора и средстава за самоконтролу;

- преглед и лечење у свим здравственим организацијама или у стану и давање лекова.

3) Мере за рано откривање, спречавање, сузбијање и лечење ендемског нефритиса које обухватају:

- пријављивање, систематске прегледе становништва и патронажне посете;

- преглед и лечење у свим здравственим организацијама и давање лекова. 
и) Здравствена заштита оболелих од прогресивних мишићних дистрофија која обухвата преглед и лечење оболелих у свим здравственим организацијама или у стану, давање специфичних лекова и патронажне посете.

j) Здравствено васпитање које обухвата систематски рад са болесним и здравим становништвом, животне демонстрације, патронаже посете, примену очигледних здравствено-васпитних средстава и уређење здравствено-васпитног амбијента, све у оквиру организованог програмског рада.

Обим мера обавезних видова здравствене заштите утврђивао се програмом за спровођење обавезних видова здравствене заштите, који је доносила Републичка односно покрајинска скупштина.

За случај повреде на раду и обољења од професионалних болести осигураницима радницима и осигураним лицима обавезно се обезбеђивало право на:

a) коришћење здравствене заштите и спровођење мера у циљу откривања и спречавања обољења од професионалних болести и повреда на раду;

б) коришћење свих врста медицинске помоћи и ортопедских средстава у циљу лечења и рехабилитације од последица повреда на раду, односно обољења од професионалне болести ради успостављања радне способности;

в) путне трошкове у вези са коришћењем здравствене заштите и рехабилитације.

Осигураницима - радницима обезбеђивало се и право на накнаду личног дохотка за све време трајања привремене спречености за рад проузроковане повредом на раду односно обољењем од професионалних болести, независно од дужине трајања здравственог осигурања.

Коришћење обавезних видова здравствене заштите и здравствене заштите за случај повреде на раду и обољења од професионалних болести обезбеђивало се у целини на терет средстава заједнице.
Осигураници - радници имали су право на накнаду личног дохотка за време привремене спречености за рад, ако су:

- услед болести или повреде привремено неспособни за рад, односно ради лечења или медицинских испитивања смештени у здравственим организацијама (привремено неспособни за рад);

- спречени да раде услед одређеног лечења или медицинских испитивања, која се не могу вршити ван осигураниковог редовног радног времена;

- изоловани као клицоноше или због појаве заразе у њиховој околини;

- одређени да негују оболелог члана уже породице или брачног друга - породиљу; - одређени за пратиоца болесника упућеног на лечење или лекарски преглед у друго место.

Накнада личног дохотка припадала је од првог дана спречености за рад и за све време трајања те спречености.

Накнаду личног дохотка за првих 30 дана спречености за рад исплаћивала је радницима организација, грађанско правно лице, односно приватни послодавац на терет својих средстава.

Заједница здравственог осигурања на терет својих средстава обавезно обезбеђивала je:

1. осигуранику - радници накнаду личног дохотка за време одсуства због трудноће и порођаја у трајању које је као најмање утврђено законом и то од првог дана тог одсуства;

2. осигуранику - радници односно раднику накнаду личног дохотка за време спречености за рад због неге болесног детета млађег од три године и то од првог дана те спречености;

3. осигуранику - радници која по истеку порођајног одсуства ради са скраћеним радним временом у смислу прописа о радним односима, због храњења детета за време проведено ван рада, припада део накнаде 
личног дохотка у износу који одговара сразмери времена проведеног ван рада према пуном радном времену.

Накнада личног дохотка за време спречености за рад због неге оболелог члана уже породице припадала је најдуже до 15 дана ако је оболели члан породице млађи од 15 година, а до седам дана ако је старији од 15 година, као и у случају неге брачног друга - породиље.

Висину накнаде личног дохотка која се исплаћивала на терет средстава заједнице здравственог осигурања, односно на терет средстава грађанско-правног лица, односно приватног послодавца, утврђивала је заједница, а висину накнаде која се исплаћивла на терет средстава организације утврђивала је организација.

Накнада личног дохотка одређивала се најмање у висини од $60 \%$ од основа за накнаду, с тим да није могла бити нижа од износа минималног личног дохотка утврђеног важећим прописима.

Висина накнаде износила $100 \%$ од основа за накнаду:

- за време привремене спречености за рад проузроковане повредом на раду или обољењем од професионалних болести;

- за време одсуства због трудноће и поpoђaja.

Радници, земљорадници и лица која су вршила самосталне професионалне делатности (осигураници), обавезно су осигуравали себе и чланове својих породица на здравствену заштиту и друга права из здравственог осигурања, у оквиру самоуправних заједница здравственог осигурања. Самоуправне заједнице здравственог осигурања истих категорија осигураника удруживале су се у заједнииу здравственог осигурања u реосигурања. Највиши орган управљања самоуправних заједница здравственог осигурања и заједницу здравственог осигурања и реосигурања била је скупштина.

\section{1. ЗАКОН О ЗДРАВСТВЕНОЈ ЗАШТИТИ ИЗ 1979. ГОДИНЕ}

Закон о здравственој заштити ${ }^{(15)}$ донет је 13. јула 1979. године. Закон је објављен у „Службеном гласнику СРС“ од 21. јула 1979. године, а ступио је на снагу осмог дана од дана објављивања. Доношењем овог закона материје из области здравствене заштите и здравственог осигурања обједињене су.

У систему здравственог осигурања централно место имале су самоуправне интересне заједнице здравствене заштите и то:

a) за територију више општина, односно за територију града Београда (међуопштинске заједнице) и

б) за територију Републике (Републичка заједница).

Основна здравствена заштита која се корисницима обезбеђивала овим законом обухватала је:

- обавезне видове здравствене заштите и мере активне здравствене заштите утврђене овим законом;

- лекарске прегледе и друге врсте медицинске помоћи у циљу утврђивања, праћења и проверавања здравственог стања;

- предузимање стручних медицинских мера и поступака за унапређивање здравственог стања односно спречавање, сузбијање и рано откривање болести и других поремећаја здравља;

- превенцију и лечење болести уста и зуба;

- лечење болесника, друге врсте медицинске помоћи и медицинску рехабилитацију у здравственим организацијама и у стану;

- лекове, помоћни материјал који служи за примену лекова и санитетски материјал потребан за лечење; 
- протезе, ортопедска и друга помагала, помоћне и санитарне справе, зубнотехничку помоћ и зубнотехничка средства.

Накнада личног дохотка за време привремене спречености за рад одређивала се најмање у висини од $70 \%$ од основа за накнаду, и није могла бити мања од износа $60 \%$ од просечног месечног чистог личног дохотка по раднику у привреди општине, односно града Београда обрачунатог у претходном периодичном обрачуну.

Накнада личног дохотка за време привремене спречености за рад проузроковане повредом на раду, професионалном болешћу, као и давањем ткива и органа, обезбеђивала се у висини од $100 \%$ од основа за накнаду личног дохотка.

Основ за утврђивање накнаде личног дохотка за време привремене спречености за рад одређивао се најмање у износу просечног месечног личног дохотка који је радник остварио у календарском полугодишту које претходи времену у којем наступа случај по коме се стицало право на накнаду.

Накнаду личног дохотка за првих 30 дана спречености за рад исплаћивала је организација, односно послодавац из својих средстава.

Самоуправне интересне заједнице, у правном систему земље постојале су до 1990. године. Круг осигураника и обим права на здравствену заштиту, за време њиховог постојања, проширен је. Основе новог система социјалног осигурања дате су у Уставу Републике Србије из 1990. године, тако да су и прописи из области здравствене заштите и здравственог осигурања почели са њиме да се уклађују.

\section{2. ЗАКОН О ЗДРАВСТВЕНОЈ ЗАШТИТИ ИЗ 1990. ГОДИНЕ}

Закон о здравственој заштити, ${ }^{(16)}$ који је слично Закону о здравственој заштити из 1979. године уређивао материју из области здравствене заштите и здравственог осигурања, донет је 25. јануара 1990. године.
У Србији од 1. априла 1990. године више не постоје СИЗ-ови здравствене заштите, уместо њих формирани су фондови.

Фондови су образовани за шире подручје од општинског, са једноставном организацијом и мањом стручном службом, што је омогућило ефикасније одлучивање.

На територији Србије било је 18 општинских фондова здравствене заштите и здравственог осигурања (сваки је покривао територију више општина) и један градски фонд здравствене заштите и здравственог осигурања (за територију града Београда).

Основна права из здравственог осигурања била су:

1) здравствена заштита;

2) накнада личног дохотка за време привремене спречености за рад;

3) накнада путних трошкова у вези са коришћењем здравствене заштите (даље: накнада путних трошкова);

4) накнада погребних трошкова.

Здравствена заштита обухватала је:

- лекарске прегледе и друге врсте медицинске помоћи у циљу утврђивања, праћења и проверавања здравственог стања;

- предузимање стручних медицинских мера и поступака за унапређивање здравственог стања, односно спречавање, сузбијање и рано откривање болести и других поремећаја здравља;

- превенцију и лечење болести уста и зуба;

- лечење оболелих и повређених и друге врсте медицинске помоћи;

- медицинску рехабилитацију у амбулантно-поликлиничким условима, болници и у кући, а у здравственим установама које спроводе специјализовану рехабилитацију деце, омладине, у случају професионалних болести и повреда на раду, после акутних обољења и повреда, као и медицинску рехабилитацију 
других обољења и стања утврђених актом Републичког фонда;

- лекове, помоћни материјал који служи за примену лекова и санитетски материјал потребан за лечење;

- протезе, ортопедска и друга помагала, помоћне и санитарне справе, стомато-протетску помоћ и стоматолошке материјале.

Обим и садржај здравствене заштите, као и начин њеног спровођења утврђивао је Републички фонд.

Накнада личног дохотка за време привремене спречености за рад одређивала се најмање у висини од 70\% од основа за накнаду, и није могла бити мања од зајемченог личног дохотка утврђеног по прописима о радним односима.

Накнада личног дохотка за време спречености за рад проузроковане повредом на раду, професионалном болешћу, као и због одржавања трудноће и давања ткива и органа, обезбеђивала се у висини од 100\% од основа за накнаду.

Основ за утврђивање накнаде личног дохотка за време привремене спречености за рад чинио је лични доходак у месецу који претходи месецу у коме је наступио случај по коме се стиче право на накнаду.

Накнаду личног дохотка за првих 30 дана спречености за рад исплаћује организација, односно послодавац из својих средстава.

Накнада путних трошкова и накнада погребних трошкова обезбеђивала се осигуранику и члану његове породице, односно домаћинства, у случају потребе, у складу са општим актом Републичког фонда.

Средства за здравствену заштиту $и$ друга права из здравственог осигурања обезбеђивала су се доприносом за здравствено осигурање из личних доходака радника, односно из одговарајућих прихода дргих радних људи и грађана и из дохотка предузећа и других организација и заједница које утврђују и распоређују доходак, као и из буџета друштвено-политичке заједнице.

\section{3. ЗАКОН О ЗДРАВСТВЕНОМ ОСИГУРАЫУ ИЗ 1992. ГОДИНЕ}

Од 1992. године материја из области здравственог осигурања поново се регулише посебним законом.

Закон о здравственом осигурағу (17) донет је 2. априла 1992. године, објављен је 4. априла и ступио је на снагу осмог дана од дана објављивања у „Службеном гласнику Републике Србије“.

За разлику од потпуне децеентрализације, која је постојала у области здравственог осигурања у периоду „слободне размене рада“, овим законом уведена је ичентрализаиија.

Здравствено осигурање на територији читаве Републике спроводило се посредством једне организације - Републичког завода за здравствено осигурање и 30 његових филијала (са испоставама) које нису имале својство правног лица ни органе. Изменама Закона о здравственом осигурању из децембра 1998. године („Службени гласник РС“, број 46/98), укинута је скупштина Републичког завода за здравствено осигурање, тако да су његови органи били управни одбор, надзорни одбор и директор.

Права из здравственог осигурања била су:

1) здравствена заштита;

2) накнада зараде за време привремене спречености за рад;

3) накнада путних трошкова у вези са коришћењем здравствене заштите и

4) накнада погребних трошкова.

Обавезним здравственим осигурањем обезбеђивана је здравствена заштита која је обухватала:

- медицинске мере и поступке за унапређивање здравственог стања, односно спречавање, сузбијање и рано откривање болести и других поремећаја здравља;

- лекарске прегледе и друге врсте медицинске помоћи у циљу утврђивања, 
праћења и проверавања здравственог стања;

- лечење оболелих и повређених и друге врсте медицинске помоћи;

- превенцију и лечење болести уста и зуба;

- медицинску рехабилитацију у амбулантно-поликлиничким и стационарним условима;

- лекове, помоћни материјал који служи за примену лекова и санитетски материјал потребан за лечење;

- протезе, ортопедска и друга помагала; помоћне и санитарне справе, стомато-протетску помоћ и стоматолошке материјале.

Осигураном лицу до 15 године живо$m a$ изузетно могло се одобрити лечење у иностранству, под условима утврђеним општим актом Завода, ако је у питању оболење и стање које се није могло лечити у Југославији, а у земљи у коју се осигураник упућивао постојале су могућности за успешно лечење тог оболења. Ограничење у погледу година живота за упућивање на лечење и иностранство укинуто је доношењем важећег Закона о здравственом осигурању 2005. години.

Накнада зараде за време привремене спречености за рад која се обезбеђивала из средстава Завода износила је $65 \%$ од основа за накнаду и није могла бити нижа од минималне зараде утврђене у складу са законом.

Накнада зараде која се обезбеђивла из средстава Завода износила је $100 \%$ од основа за накнаду и није могла бити нижа од минималне зараде утврђене у складу са законом, у случајевима када је узрок спречености за рад био: повреда на раду и професионална болест; добровољно давање ткива и органа, и одржавање трудноће.

Висина накнаде зараде коју је обезбеђивао послодавац из својих средстава утврђивала се у складу са прописима о раду и Законом о здравственом осигурању и такође износила је $100 \%$ за случајеве повреда на раду и професионална болест, добровољно давање ткива и органа, и одржавање трудноће.

Основ за утврђивање накнаде зараде чинила је зарада утврђена у складу са законом, општим актом или уговором о раду, коју би осигураник остварио у месецу за који се исплаћује накнада зараде да није наступила привремена спреченост за рад, као и накнада зараде због рада са скраћеним радним временом, односно накнада зараде због рада на другом одговарајућем послу у складу са прописима о пензијском и инвалидском осигурању.

Накнаду зараде за случајеве привремене спречености за рад за првих 30 дана спречености за рад обезбеђује послодавац из својих средстава, а после тога дана Завод. До доношења Закона о изменама и допунама Закона о здравственом осигурању, априла 2002. године („Службени гласник РC“, број 18/02), накнаду зараде за првих 60 дана спречености за рад обезбеђивао је послодавац, а после тога Завод.

Накнада зараде на терет Завода обезбеђивала се од првог дана спречености за рад осигуранику спреченом за рад због добровољног давања ткива и органа и осигуранику мајци, односно оцу, усвојиоцу или другом лицу које се стара о детету, за време привремене спречености за рад због неге болесног детета млађег од три године.

Накнада трошкова превоза припадала је у случају да осигурано лице остварује здравствену заштиту у другом месту које је удаљено најмање 30 км од његовог места становања.

У случају смрти осигураника и чланова њихових породица, лицу које изврши сахрану припадала је накнада погребних трошкова.

Накнада погребних трошкова припадала је у висини од $50 \%$ од просечне месечне зараде по запосленом на територији Републике, у претпоследњем месецу у односу на дан сахране, утврђене према податку републичког органа надлежног за посло- 
ве статистике. Доношењм важећег Закона о здравственом осигурању, 2005. године, накнада погребних трошкова, као право из здравственог осигурања, укинуто је.

\section{4. ЗАКОН О ЗДРАВСТВЕНОМ ОСИГУРАНУ ИЗ 2005. ГОДИНЕ}

Важећи Закон о здравственој зашти$m u,{ }^{(18)}$ којим долази до децентрализације у систему здравствене заштите, и Закон о здравственом осигурағу, који задржава централизацију здравственог осигурања, донети су 2005. године, са каснијим изменама и допунама.

Права из обавезног здравственог осигурања запослених и других грађана, обухваћених обавезним здравственим осигурањем, организација и финансирање обавезног здравственог осигурања, добровољно здравствено осигурање и друга питања од значаја за систем здравственог осигурања, у Републици Србији уређују се Законом о здравственом осигурању, ${ }^{(19)}$ који се примењује од 10. децембра 2005. године.

У Републици Србији, у складу са овим законом, здравствено осигурање је:

1) обавезно здравствено осигурање (здравствено осигурање којим се запосленима и другим грађанима обухваћеним обавезним здравственим осигурањем, на начелима солидарности и узајамности, као и другим начелима утврђеним законом, обезбеђују право на здравствену заштиту и право на новчане накнаде) и

2) добровољно здравствено осигурање (осигурање од настанка ризика плаћања учешћа у трошковима здравствене заштите, осигурање грађана који нису обавезно осигурани, односно који се нису укључили у обавезно здравствено осигурање, као и осигурање на већи обим и стандард и друге врсте права из здравственог осигурања).

Врсте добровољног здравственог осигурања су: 1) паралелно здравствено осигурање, 2) додатно здравствено осигурање, 3 ) приватно здравствено осигурање.
Обавезно здравствено осигурање обезбеђује се и спроводи у Републичком фонду за здравствено осигурање. Законом о изз менама и допунама Закона о здравственом осигурању, из августа 2011. године („Службени гласник РС“, број 57/ 11) Републички завод за здравствено осигурање променио је назив у Републички фонд за здравствено осигурање.

Одређени послови обавезног здравственог осигурања спроводе се и у филијалама Републичког фонда и њиховим испоставама и у Покрајинском фонду за здравствено осигурање, који немају својство правног лиия.

Добровољно здравствено осигурање могу да спроводе правна лица која обављају делатност осигурања у складу са законом, као и Републички фонд за здравствено осигурање.

Средства за остваривање права из обавезног здравственог осигурања обезбеђују се уплатом доприноса за обавезно здравствено осигурање, као и из других извора, у складу са законом.

Обавезно здравствено осигурање обухвата:

1) осигурање за случај болести и повреде ван рада;

2) осигурање за случај повреде на раду или професионалне болести.

Права из обавезног здравственог осигурања, у складу са законом, обезбеђују се:

а) осигураним лицима (осигураницима и чланови породице осигураника);

б) лицима која се укључују у обавезно здравствено осигурање;

ц) лицима којима се у одређеним случајевима обезбеђују права из обавезног здравственог осигурања и

д) држављанима, односно осигураницима земаља са којима је закључен међународни уговор о социјалном осигурању.

Осигураници су физичка лицуа која су обавезно осигурана у складу са законом, и то: 
1) лица у радном односу, односно запослена у привредном друштву, другом правном лицу, државном органу, органу јединице локалне самоуправе и аутономне покрајине, као и код физичких лица (у даљем тексту: запослени);

2) цивилна лица на служби у Војсци и војним јединицама и војним установама;

$3)$ изабрана, именована или постављена лица, ако за обављање функције остварују зараду, односно плату или накнаду зараде;

4) лица која, у складу са законом којим се уређује рад, обављају послове ван просторија послодавца;

5) лица која, у складу са законом којим се урећује рад, обављају послове кућног помоћног особља;

6) држављани Републике који су на територији Републике запослени код страних или међународних организација и установа, страних конзуларних или дипломатских представништава или су запослени код страних правних или физичких лица, ако међународним уговором није друкчије одређено;

7) лица у радном односу, односно запослени упућени на рад у иностранство, односно запослени у привредном друштву или другом правном лицу које обавља делатност или услуге у иностранству, ако нису обавезно осигурани по прописима те земље, или ако међународним уговором није друкчије одређено;

8) запослени родитељ, усвојитељ, хранитељ, односно старатељ који одсуствује са рада док дете не наврши три године живота, док му мирују права и обавезе по основу рада, у складу са прописима о раду;

9) држављани Републике запослени у иностранству код страног послодавца који немају здравствено осигурање страног носиоца здравственог осигурања или који нису обавезно осигурани према прописима стране државе, односно ако права из здравственог осигурања по прописима те државе, за себе или чланове своје породице, не могу остваривати или користити ван територије те државе;
10) страни држављани и лица без држављанства који су, на територији Републике, запослени код страних правних или физичких лица, ако међународним уговором није друкчије одређено, као и код међународних организација и установа и страних дипломатских и конзуларних представништава, ако је такво осигурање предвиђено међународним уговором;

11) држављани Републике запослени у домаћинствима држављана Републике у радном односу у иностранству код организације чије је седиште на територији Републике;

12) лица која имају право на новчану накнаду по основу незапослености, према прописима о запошљавању;

13) лица која обављају привремене и повремене послове у складу са законом којим се уређује рад (лица која нису у радном односу, запослени који раде непуно радно време - до пуног радног времена и корисници старосне пензије);

14) лица која у складу са законом обављају привремене и повремене послове преко омладинске, односно студентске задруге а имају навршених 26 година живота, односно без обзира на године живота ако нису на школовању;

15) лица која по престанку радног односа остварују право на накнаду зараде због повреде на раду или професионалне болести, у складу са овим законом;

16) лица која обављају послове по основу уговора о делу, по основу ауторског уговора, по основу уговора о породичном смештају према прописима о социјалној заштити, као и по основу других уговора код којих се за извршен посао остварује накнада (у даљем тексту: уговорена накнада);

17) лица која су оснивачи, чланови, односно акционари привредних друштава (ортачка друштва, командитна друштва, друштва са ограниченом одговорношћу, акционарска друштва и друге правне форме привредних друштава, односно предузећа), који у њима нису засновали радни однос 
али обављају одређене послове (у даљем тексту: оснивачи привредних друштава);

18) предузетници који су регистровани за обављање законом дозвољене делатности у виду занимања ради самосталног обављања делатности, обављања делатности слободне професије, као и самостални уметници, у складу са законом (у даљем тексту: предузетници);

19) спортисти, који у складу са законом којим се уређује спорт обављају спортску делатност као самосталну делатност;

20) свештеници и верски службеници који те послове обављају као самосталну делатност;

21) пољопривредници старији од 18 година живота, који обављају пољопривредну делатност као једино или основно занимање, у складу са законом, ако нису: осигураници запослени, осигураници самосталних делатности, осигураници из тачке 17) овог става, корисници пензија, лица на школовању;

22) корисници пензије и права на новчане накнаде који су ова права остварили према прописима о пензијском и инвалидском осигурању;

23) држављани Републике који примају пензију или инвалиднину искључиво од иностраног носиоца осигурања док бораве или имају пребивалиште на територији Републике, односно који примају пензију од државе са којом не постоји билатерални споразум о социјалном осигурању или ако права из здравственог осигурања по прописима државе исплатиоца пензије, за себе или чланове своје породице, не могу користити или остваривати ван територије те државе;

24) страни држављани који на територији Републике раде код домаћих организација, односно приватних послодаваца на основу посебних уговора о размени стручњака или споразума о међународној техничкој сарадњи;

25) страни држављани за време школовања или стручног усавршавања на територији Републике.
Својство осигураника може се стећи само по једном основу осигурања.

Осигураницима, у складу са чланом 22. Закона, сматрају се и лица која припадају групацији становништва која је изложена повећаном ризику оболевања; лица чија је здравствена заштита потребна у вези са спречавањем, сузбијањем, раним откривањем и лечењем болести од већег социјално-медицинског значаја; као и лица која су у категорији социјално угроженог становништва, ако не испуњавају услове за стицање својства осигураника или ако права из обавезног здравственог осигурања не остварују као чланови породице осигураника, и то:

1) деца до навршених 18 година живота, школска деца и студенти до краја прописаног школовања, а најкасније до навршених 26 година, у складу са законом; Законом о изменама и допунама Закона о здравственом осигурању, из 2011. године („Службени гласник PC“, број 57/ 11), горња граница за здравствено осигурање деце, на терет средстава буџета РС подигнута је са 15 на 18 година.

2) жене у вези са планирањем породице, као и у току трудноће, порођаја и материнства до 12 месеци након порођаја;

3) лица старија од 65 година живота;

4) особе са инвалидитетом, по прописима о пензијском и инвалидском осигурању, као и ментално недовољно развијена лица;

5) лица у вези са лечењем од ХИВ инфекције или других заразних болести које су утврђене посебним законом којим се уређује област заштите становништва од заразних болести, малигних болести, хемофилије, шећерне болести, психозе, епилепсије, мултипле склерозе, лица у терминалној фази хроничне бубрежне инсуфицијенције, цистичне фиброзе, системске аутоимуне болести, реуматске грознице, болести зависности, оболели од ретких болести; као и лица обухваћена здравственом заштитом у вези са давањем и примањем ткива и органа;

6) монаси и монахиње; 
7) материјално необезбеђена лица која примају новчану социјалну помоћ, односно која су корисници породичне инвалиднине, по прописима о социјалној заштити, односно по прописима о заштити бораца, војних инвалида и цивилних инвалида рата;

8) корисници сталних новчаних помоћи, као и помоћи за смештај у установе социјалне заштите или у друге породице, по прописима о социјалној заштити;

9) незапослена лица и друге категорије социјално угрожених лица чији су месечни приходи испод прихода утврђених у складу са овим законом;

10) корисници помоћи - чланови породице чији је хранилац на одслужењу војног рока;

11) лица ромске националности која због традиционалног начина живота немају стално пребивалиште, односно боравиште у Републици;

12) жртве насиља у породици;

13) жртве трговине људима.

У складу са чланом 12. Закона о здравственој заштити, средства за остваривање здравствене заштите лица из члана 22. 3aкона о здравственом осигурағу, у случају да нису обухваћена обавезним здравственим осигурањем, обезбеђују се у буцету Републике и преносе се организацији за обавезно здравствено осигурање.

Права из обавезног здравственог осигурањь а јесу:

1) право на здравствену заштиту;

2) право на накнаду зараде за време привремене спречености за рад осигурани$\kappa a$;

3) право на накнаду трошкова превоза у вези са коришћењем здравствене заштите.

У односу на Закон о здравственом осигурању из 1992. године изостављено је право на накнаду погребних трошкова.

Права из здравственог осигурања остварују се под условом да је доспели допринос за здравствено осигурање плаћен, ако овим законом није друкчије одређено.
Право на здравствену заштиту које се обезбеђује обавезним здравственим осигурањем обухвата:

1) мере превенције и раног откривања болести;

2) прегледе и лечење жена у вези са планирањем породице, као и у току трудноће, порођаја и материнства до 12 месеци након порођаја;

3) прегледе и лечење у случају болести и повреде;

4) прегледе и лечење болести уста и зуба;

5) медицинску рехабилитацију у случају болести и повреде;

6) лекове и медицинска средства;

7) протезе, ортозе и друга помагала за кретање, стајање и седење, помагала за вид, слух, говор, стоматолошке надокнаде, као и друга помагала (у даљем тексту: медицинско-техничка помагала).

Републички фонд може прописати претходну сагласност првостепене лекарске комисије за коришћење здравствене заштите, а посебно за одређене врсте дијагностичких и терапијских поступака, стационарно лечење или кућну негу.

У остваривању права на здравствену заштиту из обавезног здравственог осигурања, Законом је прописан проценат од цене здравствене услуге који пада на терет средстава здравственог осигурања (100\%, најмање $95 \%$, најмање $80 \%$ и најмање $65 \%$ ).

Републички фонд за сваку календарску годину доноси општи акт којим уређује садржај, обим и стандард права на здравствену заштиту из обавезног здравственог осигурања за поједине врсте здравствених услуга и поједине врсте болести, проценат плаћања из средстава обавезног здравственог осигурања до пуног износа цене здравствене услуге, као и проценат плаћања осигураног лица. ${ }^{(20)}$

Основ за обрачун накнаде зараде за време привремене спречености за рад осигураника, као једног од права из области здравственог осигурања, коју исплаћује послодавац из својих средстава, утврђује се у складу 
са прописима о раду, а за обрачун накнаде зараде која се исплаћује из средстава обавезног здравственог осигурања основ чини просечна зарада коју је осигураник остварио у претходна три месеща пре месеща у којем је наступила привремена спреченост за рад.

Зараду која се исплаћује из средстава обавезног здравственог осигурања чини зарада за обављени рад и време проведено на раду, утврђена у складу са прописима о раду, и то: основна зарада запосленог и увећана зарада по основу времена проведеног на раду за сваку пуну годину рада остварену у радном односу.

Висина накнаде зараде коју обезбеђује послодавац за првих 30 дана спречености за рад осигураника из својих средстава утврђују се у складу са прописима о раду и законом.

Висина накнада зараде која се обезбеђује из средстава обавезног здравственог осигурања, као и из средстава послодаваца износи $65 \%$ од основа за накнаду зараде.

Висина накнаде зараде која се обезбеђује из средстава обавезног здравственог осигурања, као и из средстава послодавца, у случајевима професионалне болести или повреде на раду, као и добровољног давања органа и ткива, изузев добровољног давања крви, износи $100 \%$ од основа за накнаду зараде.

Висина накнаде зараде која се обезбеђује из средстава обавезног здравственог осигурања не може бити нижа од минималне зараде утврђене у складу са прописима о раду за месец за који се врши обрачун накнаде зараде, нити виша од 65\%, односно 100\% највишег основа за накнаду зараде утврђеног у складу са овим законом.

Накнада трошкова превоза у вези са коришћењем здравствене заштите обезбеђује се осигураним лицима, као и пратиоцу осигураног лица, у случају упућивања у здравствену установу ван подручја матичне филијале, ако је здравствена установа удаљена најмағе 50 километара од места његовог становања.
Односи између матичне филијале, односно Републичког фонда и давалаца здравствених услуга, поводом остваривања права осигураних лица на здравствену заштиту, уређују се уговором.

Доношењем Закона о изменама Закона о здравственом осигурағу („Службени гласник РС“, бр. 123/14), број чланова управног одбора Републичког фонда смањен je са 21 на 7 чланова (од којих се четири именују на предлог министра надлежног за послове здравља), а број чланова надзорног одбора смањен је са 7 на 5 чланова (од којих се три именују на предлог министра надлежног за послове здравља), чиме министарство надлежно за послове здравља преузима функцију управљања Републичким фондом.

\section{ЗАКЉУЧАК}

Реформа система здравствене заштите је континуиран и унапред добро осмишљен, процес.

При реформисању система здравствене заштите, поред искустава других земаља, у првом реду земаља са сличним системом, значајна су и властита искуства, а у чему Србија не оскудева.

Историја развоја здравственог осигурања у Србији дуга је више од 130 година. У овом раду, као и у претходном, ${ }^{(1)}$ аутори су указали само на основне правце у развоју организације, финансирања и садржаја и обима права из области здравственог осигурања. Међутим, и тај увид указује нам неопходност и корисност детаљнијег изучавања развоја система здравственог осигурања у Србији у претходном периоду, а све у циљу што бољег осмишљавања његовог даљег развоја. 


\section{ЛИТЕРАТУРА}

1. Рајко Косановић, Христо Анђелски: Оановни правци развоја здравственог осигурања у Републици Србији (19222014.), Здравствена заштита, Београд, 2015; 3 : .

2. Законом о осигурању радника, „Службене новине” број 117/22.

3. Закон о спровођењу социјалног осигурања на подручју Демократске Федеративне Југославије, „Службени лист ДФЈ“, број 29/45.

4. Закон о социјалном осигурању радника намештеника и службеника, „Службени лист ФНРЈ“, број 65/46.

5. Закон о социјалном осигурању радника и службеника и њихових породица, „Службени лист ФНРЈ“, бр. 10/50, 13/50, $4 / 51,11 / 51$ и 46/51.

6. Закон о здравственом осигурању радника и службеника, „Службени лист ФНРЈ“, број 51/54.

7. Закон о пензијском осигурању, „Службени лист ФНРЈ“, број 51/57.

8. Закон о инвалидском осигурању, „Службени лист ФНРЈ“, број 49/58.

9. Уредба о фондовима за узајамно помагање, „Службени лист ФНРЈ“, број $51 / 56$.

10. Закон о установљењу здравственог осигурања пољопривредних произвођача, „Службени лист ФНР””, број 27/59.

11. Закон о здравственом осигурању, „Службени лист ФНРЈ”, број 22 /62 и 53 162.
12. Закон о изменама и допунама Закона о здравственом осигурању, „Службени лист СФРЈ”, бр. 15/65, 29/66, 52/66 и 23/67.

13. Општи закон о здравственом осигурању и обавезним видовима здравствене заштите становништва, „Службени лист СФРЈ”, број 20/69.

14. Закон о здравственом осигурању и обавезним видовима здравствене заштите становништва, „Службени гласник СРС”. број 27/70.

15. Закон о здравственој заштити, „Службени гласник СРС“, бр. 30/79, 59/82, 18/83, 22/84, 50/84, 51/85, 49/86, 22/87, 35/87 - исправка, 42/87 пречишћен текст, 46/87 - исправка, 8/88 и $20 / 89$.

16. Закон о здравственој заштити, „Службени гласник СРС“, број 4/90.

17. Закон о здравственом осигурању, „Службени гласник РС“ бр. 18/92, 26/93, 53/93, 67/93, 48/94, 25/96, 46/98, 54/99, $29 / 2001$ и $18 / 2002$ ).

18. Закон о здравственој заштити, „Службени гласник РС“, бр. 107/05, 72/09 - др. закон, 88/10, 99/10, 57/11, 119/12, 45/13 - др. закон и 93/14.

19. Закон о здравственом осигурању, „Службени гласник РC“, бр. 107/05, 109/09 - исправка, 57/11, 110/12 - УС, $119 / 12,99 / 14$ и 123/14.

20. Правилник о садржају и обиму права на здравствену заштиту из обавезног здравственог осигурања и о партиципацији за 2015. годину, „Службени гласник РС“, број 1/15.

Контакт: Рајко Косановић, e-mail: drrajko.kosanovic@gmail.com 